\section{Multippel sklerose hos innvandrere i Norge}

\author{
Innvandrere får sjeldnere multippel sklerose enn norskfødte, men kan \\ bli hardere rammet om de først blir syke.
}

Det er vist at forekomsten av multippel sklerose øker med avstanden til ekvator. Stadig flere kommer til Norge fra land med lavere forekomst av multippel sklerose enn her i landet. Vi mistenkte raskere sykdomsutvikling hos ikke-vestlige innvandrere enn i befolkningen generelt.

Data fra Norsk MS-register og -biobank, Oslo MS-register, Norsk pasientregister, Reseptregisteret og Statistisk sentralbyrå ble koblet anonymt. I denne første nasjonale undersøkelsen fant vi at prevalensen av multippel sklerose i Norge per 1.1. 2012 var 203/100 000 - blant de høyeste i verden. Det var regionale forskjeller i forekomst, men ingen sammenheng med breddegrad. Forekomsten av multippel sklerose i de fleste innvandrergrupper i Norge var lav, men den var høy blant førstegenerasjonsinnvandrere fra Iran. Vi fant at ikke-vestlige innvandrere med multippel sklerose i Oslo hadde raskere sykdomsprogrediering enn etniske nordmenn og vestlige innvandrere. De fikk også oftere sykdomsmodifiserende behandling.

Pålitelige estimater av forekomsten av multippel sklerose er viktig for å kunne tilrettelegge helsetjenestetilbudet.

Endret forekomst av multippel sklerose etter migrasjon og mer alvorlig sykdomsutvikling peker mot faktorer i det norske miljøet som er av betydning for risikoen og som potensielt kan påvirkes. I vår studie identifiserte vi også grupper av pasienter som kan ha behov for spesiell årvåkenhet og oppfølging.

Pål Berg-Hansen

pberghansen@gmail.com

\title{
Overvektskirurgi bedrer lavgradig inflammasjon
}

Det er signifikant forskjell i inflammatoriske markører hos sykelig overvektige pasienter og hos normalvektige. Etter overvektskirurgi er ikke forskjellen lenger til stede.

Sykelig overvektige pasienter er i risikogruppen for utvikling av tilleggssykdommer som diabetes mellitus type 2, hypertensjon og kardiovaskulær sykdom. Mekanismene bak utviklingen av tilleggssykdommer er ikke fullstendig kartlagt, men lavgradig inflammasjon og visceralt fettvev er assosiert med utviklingen av disse tilleggssykdommene.

I denne prospektive studien undersøkte vi hvordan livsstilsendringer etterfulgt av overvektskirurgi påvirker markører for glukosemetabolisme, inflammasjon og koagulasjon. 134 pasienter med sykelig overvekt og 36 normalvektige pasienter ble inkludert. Pasientene med sykelig overvekt ble fulgt i ett år etter kirurgi. De 36 normalvektige pasientene inngikk som kontrollgruppe.

Vi har vist at markører for lavgradig inflammasjon, som for eksempel hs-CRP, C3 og C4 i serum, var signifikant høyere i gruppen med sykelig overvekt ved inklutige var ikke lenger signifikant. Videre har vi sammenlignet konsentrasjonen av bakteriell DNA i forskjellige fettvevskompartmenter mellom de to gruppene. Vi fant et økende innhold av bakterielt DNA hos de sykelig overvektige jo nærmere man kom tarmen. En slik gradient var ikke til stede hos de normalvektige.

Våre funn peker på at lavgradig inflammasjon og tarmens mikrobiota kan være sentrale faktorer i utviklingen av tilleggssykdommer hos pasienter med sykelig overvekt. Kirurgisk behandling, med påfølgende betydelig vekttap, reduserer nivået av markører for lavgradig inflammasjon.

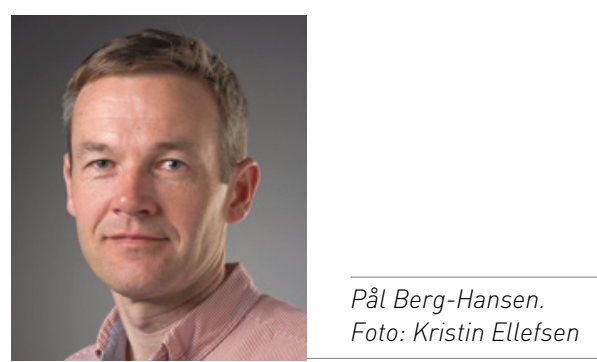

Disputas

Pål Berg-Hansen disputerte for ph.d.-graden ved Universitetet i Oslo 4.5. 2015. Tittelen på avhandlingen er Clinical and epidemiological studies of immigrants with multiple sclerosis in Norway.

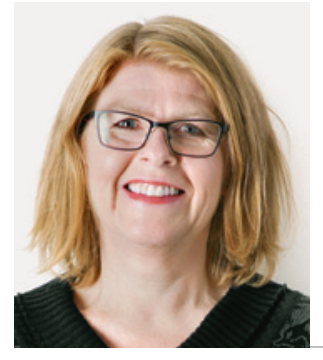

Torunn Kristin Nestvold. Foto: Stian Throndsen

Disputas

Torunn Kristin Nestvold disputerte for ph.d.graden ved Universitetet i Troms $\varnothing$ 8.6. 2015. Tittelen på avhandlingen er $A$ study of changes in glucose metabolism and inflammatory markers in morbidly obese patients undergoing bariatric surgery. 